\title{
Photodynamic therapy of a 2-methoxyestradiol tumor-targeting drug delivery system mediated by Asn-Gly-Arg in breast cancer
}

This article was published in the following Dove Press journal:

International Journal of Nanomedicine

19 April 2013

Number of times this article has been viewed

Jinjin Shi

Zhenzhen Wang

Lei Wang

Honghong Wang

Lulu Li

Xiaoyuan Yu

Jing Zhang

Rou Ma

\section{Zhenzhong Zhang}

School of Pharmaceutical Sciences, Zhengzhou University, Zhengzhou, People's Republic of China
Correspondence: Zhenzhong Zhang School of Pharmaceutical Sciences, Zhengzhou University, 100 Kexue Avenue, Zhengzhou, 45000I, People's Republic of China Tel $+8637 \mid 6778$ I9I0 Fax $+8637 \mid 67781908$ Email zhangzz08@I26.com

\begin{abstract}
Fullerene (C60) has shown great potential in drug delivery. In this study we exploited modified fullerene (diadduct malonic acid-fullerene-Asn-Gly-Arg peptide [DMA-C60-NGR]) as an antitumor drug carrier in order to build a new tumor-targeting drug delivery system. We also investigated the synergistic enhancement of cancer therapy using photodynamic therapy (PDT) induced by DMA-C60-NGR and 2-methoxyestradiol (2ME). Cytotoxicity tests indicated that DMA-C60-NGR had no obvious toxicity, while our drug delivery system (DMA-C60-2ME-NGR) had a high inhibition effect on MCF-7 cells compared to free $2 \mathrm{ME}$. The tumor-targeting drug delivery system could efficiently cross cell membranes, and illumination induced the generation of intracellular reactive oxygen species and DNA damage. Furthermore, DMA-C60-2ME-NGR with irradiation had the highest inhibition effect on MCF-7 cells compared to the other groups. DMAC60-NGR combined with $2 \mathrm{ME}$ showed a good synergistic photosensitization effect for inhibiting the growth of MCF-7 cells, demonstrating that DMA-C60-2ME-NGR may be promising for high treatment efficacy with minimal side effects in future therapy.
\end{abstract}

Keywords: fullerene, drug delivery system, photodynamic therapy, tumor targeting

Fullerene (C60) was discovered in 1985 and is composed of 60 carbon atoms arranged in a spherical structure that contains 12 pentagons and 20 hexagons. Due to its unique physicochemical and optical properties, C60 is diffusely used for materials and electrical applications, while its biological applications are limited owing to its high hydrophobicity. Pristine C60 is more toxic than its derivatives $;{ }^{1}$ consequently, many water-soluble derivatives of $\mathrm{C} 60$ have been synthesized by bonding various functional groups $\left(-\mathrm{OH},-\mathrm{COOH},-\mathrm{NH}_{2}\right.$ and others) to the fullerene cage. ${ }^{2-4}$ Functional fullerenes have many potential biological activities, such as enzymatic inhibition, antihuman immunodeficiency virus activity, antibacterial activity, antitumor activity, DNA cleavage, and photodynamic therapy, ${ }^{5,6}$ and play important roles as drug carriers for selective tissue targeting. ${ }^{7,8}$ Recently, an amphiphilic fullerene (buckysome) was explored as a vector for paclitaxel and was found to be equi efficacious to Abraxane, a commercially available albumin-bound nanoformulation of paclitaxel. ${ }^{9}$ Photodynamic therapy (PDT) has been applied in the treatment of some malignant tumors; this therapy uses visible light to activate tumor-localizing photosensitizers, which produce reactive oxygen species (ROS) that lead to its cytotoxic effect. ${ }^{10-12}$ Malonic acid C60 derivatives were found to kill cells upon exposure to ultraviolet (UV) or plain visible light by generating ROS through PDT, and the ROS decreased with the increasing number of addends. ${ }^{13,14}$ In this study, we synthesized diadduct malonic acid C60 (DMA-C60) with a high water solubility and high PDT activity. 
Angiogenic tumor vessels are important elements for tumor growth and metastasis, and extensive laboratory data suggest that angiogenesis plays an essential role in breast cancer development, invasion, and metastasis. ${ }^{15,16}$ Aminopeptidase $\mathrm{N}$ (APN)/CD13 isoform, the tumor vascular antigen, ${ }^{17,18}$ is selectively overexpressed in tumor vasculature and certain tumor cells. It plays multiple functions as a regulator of hormones and cytokines, protein degradation, antigen presentation, cell proliferation, cell migration, and angiogenesis. ${ }^{19}$ The AsnGly-Arg (NGR) peptide motif can selectively recognize the CD13 isoform and has been used as a potent tumor-targeting ligand for target drugs to improve biodistribution. ${ }^{20-23}$ NGR has been certified useful for delivering chemotherapeutic drugs, apoptotic peptides, and liposomes to tumor vessels. ${ }^{2,22,23}$ Consequently, NGR was conjugated to DMA-C60, forming a novel tumor-targeting drug carrier.

2-Methoxyestradiol (2ME), a nonpolar endogenous metabolite of $17 \beta$-estradiol, exhibits antiproliferative and antiangiogenic activities in some human cancer cell lines in vitro and in vivo. ${ }^{24-27}$ Moreover, antiproliferative effects were observed in the estrogen receptor-positive human breast adenocarcinoma cell line (MCF-7). ${ }^{28,29}$ In addition, $2 \mathrm{ME}$ induces apoptosis in some tumor cell lines but not in normal cells. ${ }^{30}$ The mechanisms of action of $2 \mathrm{ME}$ relates to tubulin depolymerization, upregulation of $\mathrm{p} 53$ and death receptors, as well as production of ROS. ${ }^{31} 2 \mathrm{ME}$ is a hydrophobic antitumor compound with limited biological accessibility and strong liver first-pass effect. ${ }^{32}$ Therefore, a new tumor-targeting

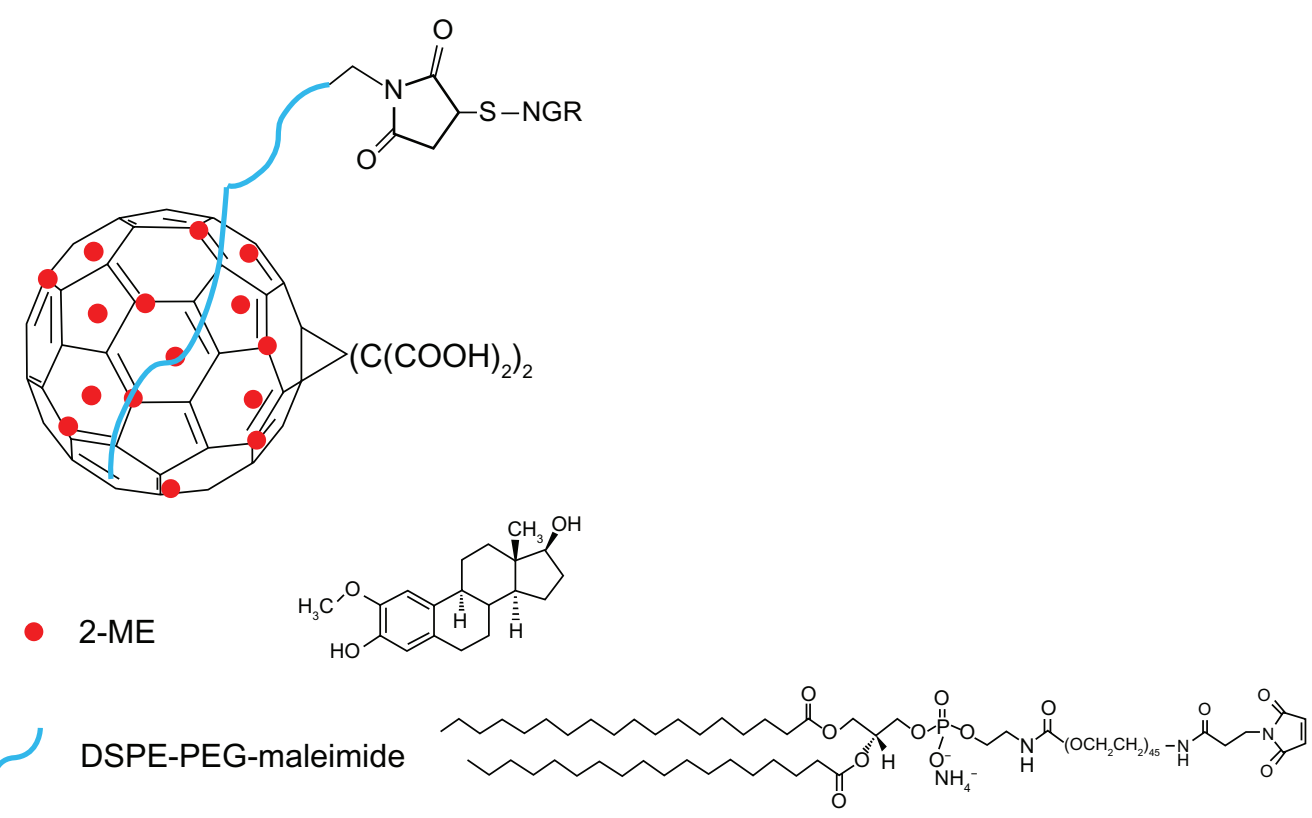

Figure I Scheme of DMA-C60-2ME-NGR.

Abbreviations: DSPE-PEG,I,2-distearoyl-sn-glycero-3-phosphoethanolamine-N-[methoxy(polyet hylene glycol)-2000]; NGR, (Asn-Gly-Arg) peptide; 2ME, 2-methoxyestradiol. drug delivery system DMA-C60-2ME-NGR (Figure 1) was explored to overcome the above-mentioned limitations.

In this study, the C60 derivative of malonic acid (DMAC60) was synthesized by Bingle cycloaddition and ester hydrolysis reactions, as documented in the literature..$^{14,33}$ DSPE-PEG2000-maleimide (DPM) was connected to DMAC60 at the DSPE extremity through a dispersing effect, and NGR was conjugated to DMA-C60 by addition reaction at the maleimide extremity. $2 \mathrm{ME}$ was then attached to DMAC60-NGR through physisorption, forming a new tumortargeting drug delivery system DMA-C60-2ME-NGR. We examined the photosensitive effect of DMA-C60-NGR with a phototoxicity assay, detection of DNA fragmentation, and intracellular ROS. In addition, we investigated the synergistic enhancement of breast cancer therapy using PDT induced by DMA-C60-NGR and 2ME.

\section{Materials and methods Materials}

Fullerene (C60, purity $>99 \%$ ) was purchased from Henan Fengyuan Chemicals Co, Ltd (Puyang, People's Republic of China). NGR peptides $\left(\mathrm{CNGRCK}_{2} \mathrm{HK}_{3} \mathrm{HK}_{11}\right)$ were synthesized by Shanghai Botai Biotechnology Co, Ltd. 2ME was homemade in our lab (purity $>98 \%$, batch number 20120304). Diethyl bromomalonate, $\mathrm{NaH}$, DPM, fluorescein isothiocyanate (FITC), dimethyl sulfoxide (DMSO), sulforhodamine B (SRB), Hoechst-33258, low-melting-point agarose (LMA), and normalmelting-point agarose (NMA) were purchased from Sigma- 
Aldrich. Other reagents were purchased from the China National Medicine Corporation and used as received. The MCF-7 cancer cell line was obtained from the Chinese Academy of Sciences Cell Bank. Roswell Park Memorial Institute medium (RPMI) 1640 cell culture medium, fetal bovine serum, penicillin, and streptomycin were purchased from Beijing Solarbio Science and Technology Co, Ltd.

\section{Synthesis of DMA-C60}

Diethyl bromomalonate $(0.2 \mathrm{~mL})$ dissolved in toluene $(3 \mathrm{~mL})$ was added dropwise to a stirred anhydrous toluene solution $(50 \mathrm{~mL})$ containing $\mathrm{C} 60$ (50 mg) and $\mathrm{NaH}(0.3 \mathrm{~g})$. After stirring at room temperature under $\mathrm{N}_{2}$ for 5 hours, the mixture was concentrated and then applied to a column chromatography $\left(\mathrm{SiO}_{2}\right)$ to obtain the diadduct malonate derivative of $\mathrm{C} 60$.

The diadduct malonate derivative of $\mathrm{C} 60(50 \mathrm{mg})$ and $\mathrm{NaH}$ $(180 \mathrm{mg})$ were added to anhydrous toluene $(30 \mathrm{~mL})$ and stirred at $80^{\circ} \mathrm{C}$ under $\mathrm{N}_{2}$ for 10 hours. Concentrated $\mathrm{HCl}(20 \mathrm{~mL})$ was then added to the reaction precipitate, followed by removing toluene. The precipitate was dispersed in concentrated $\mathrm{HCl}$, filtered, and washed with $\mathrm{H}_{2} \mathrm{O}$ and $\mathrm{MeOH}$. The resulting solid was dissolved in $\mathrm{MeOH}$, and the insoluble products were removed by filtering. After evaporation, the solid products were dried in a vacuum at $50^{\circ} \mathrm{C}$ for 24 hours.

\section{NGR conjunction}

DMA-C60 (50 mg) and DPM (5 mg) were added to ultra-pure water $(10 \mathrm{~mL})$. After sonication for 2 hours, the solution was centrifuged at $4000 \mathrm{r} /$ minute to remove large particles. The NGR (Cys-Asn-Gly-Arg [CNGR]) water solution was then added to the DMA-C60 and DPM suspension with NGR and maleimide in a molar ratio of $1: 20 .{ }^{34}$ After being left to stand overnight at room temperature, DMA-C60-NGR was obtained as a solid by freeze-drying, which was washed with $\mathrm{H}_{2} \mathrm{O}$ through a membrane filter to remove excess NGR. After freeze drying, the solid products were dried in vacuum at $30^{\circ} \mathrm{C}$ for 24 hours and stored at $4^{\circ} \mathrm{C}$ until use.

Thin layer silica gel chromatography, with n-butanolwater-acetic acid $(4: 2: 1)$ as the developing agent and ninhydrin solution $0.5 \%$ as the coloring agent, was used to test for conjugation of NGR to DMA-C60. ${ }^{34}$

\section{Conjugation of 2ME to DMA-C60-NGR}

DMA-C60-NGR (50 mg) was added to ethanol (3 mL) containing 2ME (100 mg). After evaporation to remove ethanol, the product was dispersed in water $(10 \mathrm{~mL})$ and sonicated with the Ultrasonic Cell Disruption System (JY92-IID; Ningbo Scientz Biotechnology Co, Ltd) twelve times at $400 \mathrm{~W}$. The nanosuspension was then centrifuged to remove free $2 \mathrm{ME}$. The resulting DMA-C60-2ME-NGR nanosuspension was stored at $4^{\circ} \mathrm{C}$ until use.

\section{Characterization of DMA-C60-2ME-NGR} Determination of size distribution and zeta potential DMA-C60-NGR and DMA-C60-2ME-NGR nanosuspensions were diluted with ultra-pure water, and their size distributions and zeta potentials were measured using the Nano-ZS90 (Malvern Instruments, Malvern, UK).

\section{Morphological observation through atomic force microscopy}

Atomic force microcopy (AFM) images were obtained in the acoustic alternating current mode on a molecular imaging picoplus system (MFP-3D; SA Asylum Research Goleta, CA, USA) equipped with a multipurpose scanner for a maximum area of $10 \mu \mathrm{m} \times 10 \mu \mathrm{m}$.

\section{Determination of 2ME loading on DMA-C60-NGR} DMA-C60-2ME-NGR was diluted with ethanol and sonicated to ensure that $2 \mathrm{ME}$ was dissolved completely and then centrifuged to separate DMA-C60-NGR and 2ME to determine the amount of $2 \mathrm{ME}$ bound to DMA-C60-NGR. The concentration of $2 \mathrm{ME}$ in ethanol was determined by UV-visible (UV-VIS) spectrophotometry (UV-2102; UNICO [Shanghai] Instruments Co, Ltd) at $288 \mathrm{~nm}$ and the concentration of DMA-C60-NGR at an absorbance of $360 \mathrm{~nm}$ (A360).

\section{Cell culture}

MCF-7 cells were cultured in RPMI 1640 supplemented with $10 \%$ fetal bovine serum (FBS) and 1\% penicillinstreptomycin at $37^{\circ} \mathrm{C}$ and $5 \% \mathrm{CO}_{2}$.

\section{Irradiation conditions}

The light source used was a white light fitted with a light guide containing a bandpass filter (400-700 nm) with an irradiance of 8900 lux as measured with a digital light meter (Hangzhou Hongpu Optoelectronics Technology Co, Ltd). Light intensity at the treatment site was $60 \mathrm{~mW} / \mathrm{cm}^{2}$.

\section{Photosensitization}

\section{Phototoxicity assay}

MCF-7 cells were incubated with $1,2,5$, or $10 \mu \mathrm{g} / \mathrm{mL}$ DMA-C60-NGR in 96-well plates for 24 hours and then exposed to visible light for 1 hour. After incubation for 24 hours, an SRB assay was performed to determine cell 
viability. The same procedure was carried out without irradiation for determining dark toxicity.

\section{Determination of intracellular ROS}

MCF-7 cells were incubated with $5 \mu \mathrm{g} / \mathrm{mL}$ DMA-C60NGR for 24 hours. We then added $5 \mu \mathrm{g} / \mathrm{mL} 5$-(and-6)chloromethyl-2'-7'-dichlorodihydrofluoresceindiacetate (CM-H ${ }_{2}$ DCFDA; Molecular Probes, Invitrogen) in complete medium and incubated the cells at $37^{\circ} \mathrm{C}$ for 30 minutes, after which cells were washed with phosphate buffered saline (PBS). We then exposed cells to $300 \mathrm{~mW}$ of a $532 \mathrm{~nm}$ laser (Changchun Laser Research Center) for 5 minutes. A fluorescence microscope (Carl Zeiss MicroImaging Co, Ltd) was used to image the cells.

\section{Detection of DNA fragmentation}

MCF-7 cells $\left(\sim 1 \times 10^{4}\right.$ cells/well $)$ were inoculated in 24-well plates in the dark for 24 hours, and then DMA-C60-NGR was added to each well at a final concentration of $5 \mu \mathrm{g} / \mathrm{mL}$. After 24 hours incubation, the 24-well plates were exposed to visible light for 1 hour, and the cells were collected and resuspended in $200 \mu \mathrm{L}$ prewarmed LMA. The cell-LMA suspension $(100 \mu \mathrm{L})$ was then gently stratified by a tip on a microscope slide that was precoated with NMA; the slides were dipped into cold lysis solution (Beijing CoWin Bioscience Co, Ltd) for 2 hours, and then put into a Coplin jar filled with electrophoresis buffer where they were left for 25 minutes to allow DNA unwinding. After electrophoresis, the slides were transferred to a tray filled with neutralization buffer at room temperature in the dark for 45 minutes, then dried at room temperature and stained in the dark with $2 \%$ ethidium bromide for observing by fluorescent microscopy (Carl Zeiss MicroImaging Co, Ltd).

\section{MCF-7 cell apoptosis monitored}

by the Hoechst-33258 assay

Changes in cell morphology were analyzed using fluorescence microscopy. After fixation with methanol at $-20^{\circ} \mathrm{C}$ for $10 \mathrm{~min}$, cells were stained with Hoechst-33258 $(10 \mu \mathrm{g} / \mathrm{mL}$ in distilled water for 5 minutes) to visualize DNA chromatin. After being washed and air dried, preparations were observed under UV excitation and apoptotic cells were counted.

\section{Cellular uptake assay}

FITC $(0.1 \mathrm{mg})$ in DMSO $(1 \mathrm{mg} / \mathrm{mL})$ was added to DMAC60-NGR $(5 \mathrm{~mL})$ and then sonicated with the Ultrasonic Cell Disruption System to get DMA-C60-NGR-FITC. The excess FITC was removed by the Sephadex G-25 column (SigmaAldrich). DMA-C60-FITC was then prepared by using the same procedure. MCF-7 cells were seeded on the cover glass slides in six-well plates for 24 hours, and DMA-C60-NGRFITC and DMA-C60-FITC were added to each well at a final DMA-C60 concentration of $2.5 \sim 5 \mu \mathrm{g} / \mathrm{mL}$, respectively. The incubations were carried out at $37^{\circ} \mathrm{C}$ and $5 \% \mathrm{CO}_{2}$ for 0.5 , 1 , and 3 hours, respectively. At indicated time points, the cell medium was removed, and the cover glass slices were washed with PBS, followed by soaking for 15 minutes in 4\% paraformaldehyde solution, and then washed with deionized water. Finally the cells were imaged by a Zeiss LSM 510 Confocal Microscope (Carl Zeiss MicroImaging Co, Ltd).

\section{Inhibition of cell growth by DMA-C60- 2ME-NGR}

MCF-7 cancer cells were cultured in standard medium. Cells were plated in 96-well plates and treated with different concentrations of DMA-C60-NGR for 72 hours to investigate the cytotoxicity of the blank delivery system. Cells were also treated with DMA-C60-2ME-NGR, DMA-C60-2ME, and 2ME (with the same 2ME dosage gradients and a weight ratio of DMA-C60-2ME of 1:1.39) for 24, 48, and 72 hours. Cell growth inhibition after various treatments was measured by SRB assay.

\section{Synergistic enhancement of cancer therapy of $2 \mathrm{ME}$ in combination with PDT}

MCF-7 cancer cells were cultured in the standard medium. Cells were plated in 96-well plates and treated with different concentrations of DMA-C60-2ME-NGR for 24 hours. The irradiating group had the same treatment as the nonirradiating group with the exception of illumination for 1 hour at 24 hours. Cell growth inhibition after various treatments was measured by SRB assay.

\section{Statistical analysis}

Quantitative data were expressed as mean \pm standard deviation. Means were compared using Student's $t$-test. $P$-values $<0.05$ were considered statistically significant.

\section{Results and discussion Characterization of DMA-C60-NGR}

In this study, we synthesized DMA-C60 by Bingle cycloaddition and ester hydrolysis reactions based on procedures provided in the literature with minor modifications (Figure 2). ${ }^{14,34}$ The results of the infrared spectroscopy (FT-IR) showed four characteristic peaks of $\mathrm{C} 60$ at approximately $1428 \mathrm{~cm}^{-1}, 1181 \mathrm{~cm}^{-1}, 576 \mathrm{~cm}^{-1}$, and $526 \mathrm{~cm}^{-1}$ (Figure 3) $)^{35}$ and new peaks at approximately $1716 \mathrm{~cm}^{-1}(\mathrm{C}=\mathrm{O})$ and 

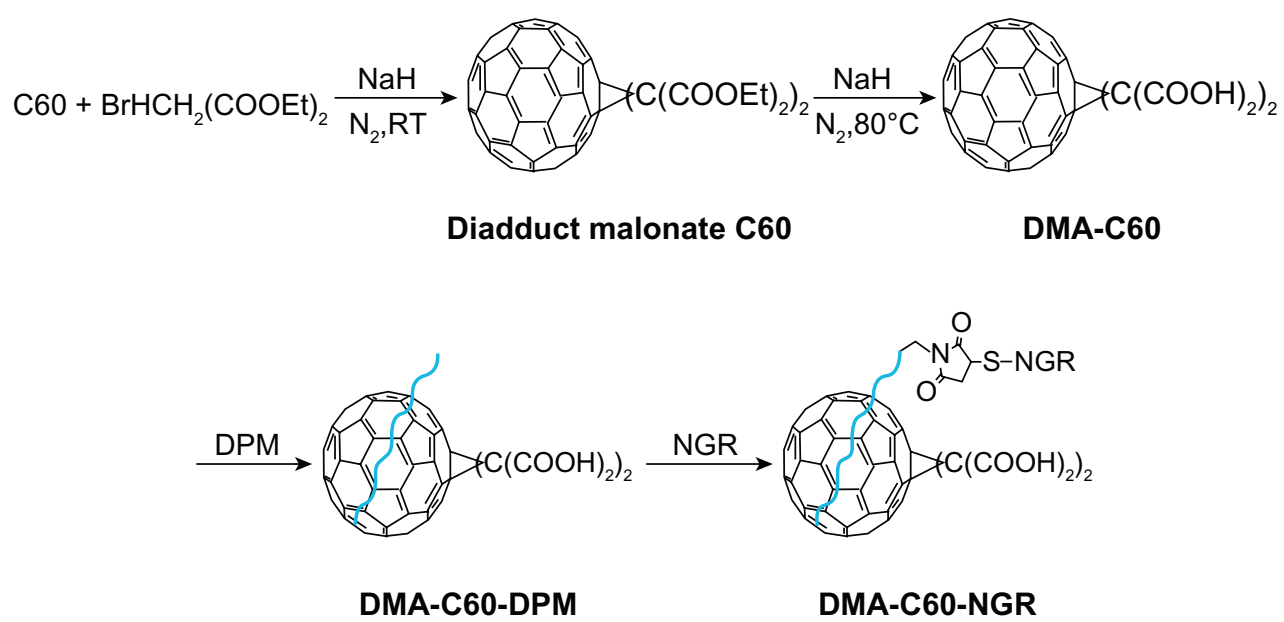

Figure 2 Scheme of preparation of DMA-C60.

Abbreviation: DPM, I,2-distearoyl-sn-glycero-3-phosphoethanolamine-N-[metho xy(polyethylene glycol)-2000]-maleimide; DMA-C60, diadduct malonate derivative of C60; NGR, (Asn-Gly-Arg) peptide.

$3427 \mathrm{~cm}^{-1}(\mathrm{O}-\mathrm{H})$ on the spectrum of DMA-C60 compared to $\mathrm{C} 60$, suggesting that the functionalization of $\mathrm{C} 60$ with $-\mathrm{COOH}$ was successful.

The DSPE-PEG-maleimide conjugate, which could undergo an addition reaction with a double bond in the sulfhydryl groups at room temperature, covalently reacted with cysteine in $\mathrm{CNGRCK}_{2} \mathrm{HK}_{3} \mathrm{HK}_{11}$ (C, containing the sulfhydryl groups). ${ }^{36}$ Results of thin layer silica gel chromatography showed that there was no free NGR after the reaction of DMA-C60 with NGR, while free NGR was found in the mechanically mixed DMA-C60 and NGR, demonstrating that NGR had been completely attached to the surface of DMA-C60 through an addition reaction.

Dynamic light scattering showed that the size and zeta potential of DMA-C60-NGR were $148 \pm 2.1 \mathrm{~nm}$ and $-25.7 \pm 2.2 \mathrm{mV}$, respectively (Figure 4C). AFM images (Figure 4D) indicated that DMA-C60-NGR had a uniform size and a ball-like structure. DMA-C60-NGR solution can be kept stable for several weeks or even months without aggregation due to its high potential (Figure 4A). NGR plays the role of an angiogenesis-targeting peptide in the

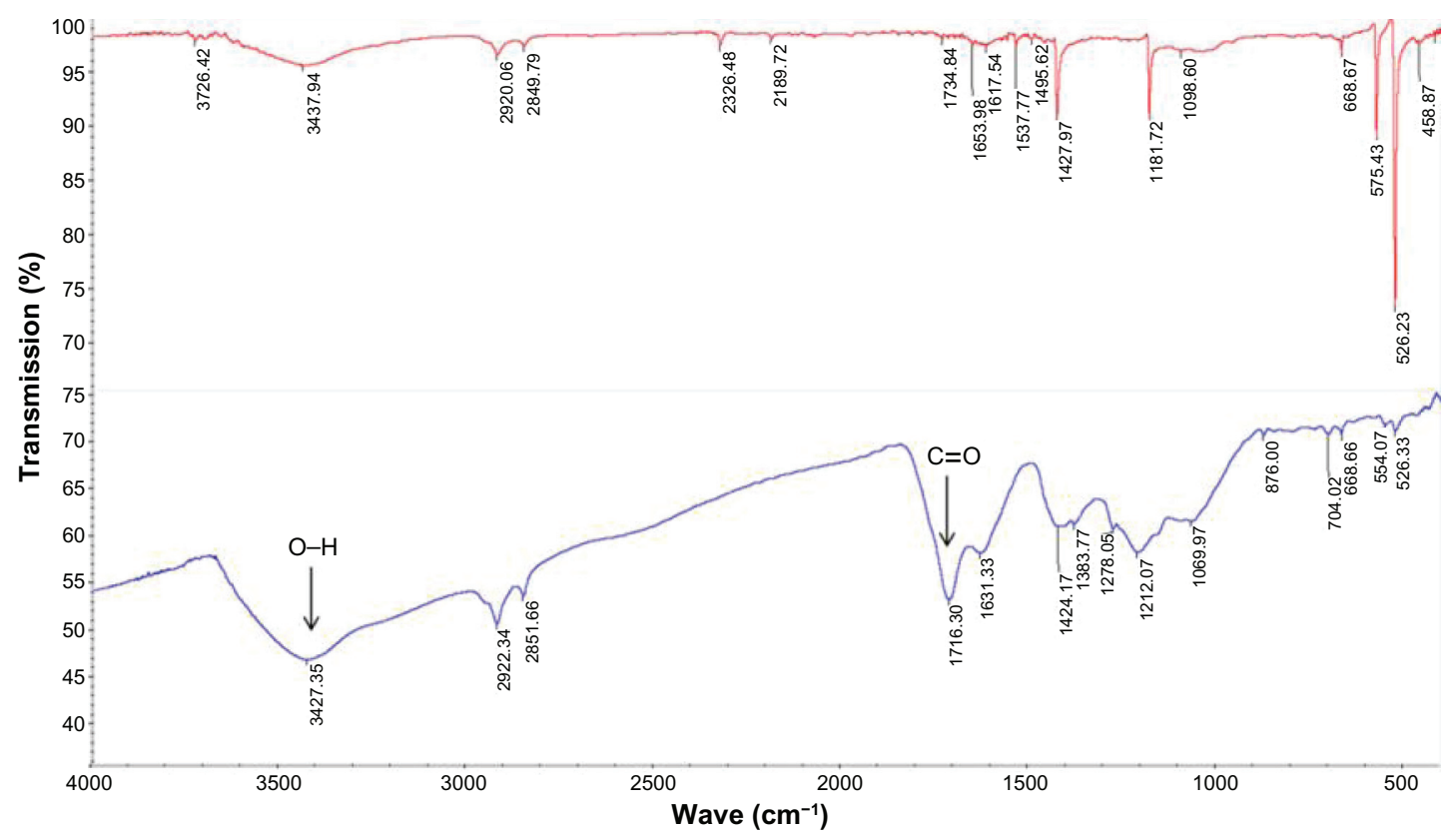

Figure 3 FT-IR spectrum.

Notes: Upper, pristine C60; lower, DMA-C60.

Abbreviation: DMA-C60, diadduct malonate derivative of $\mathrm{C} 60$. 

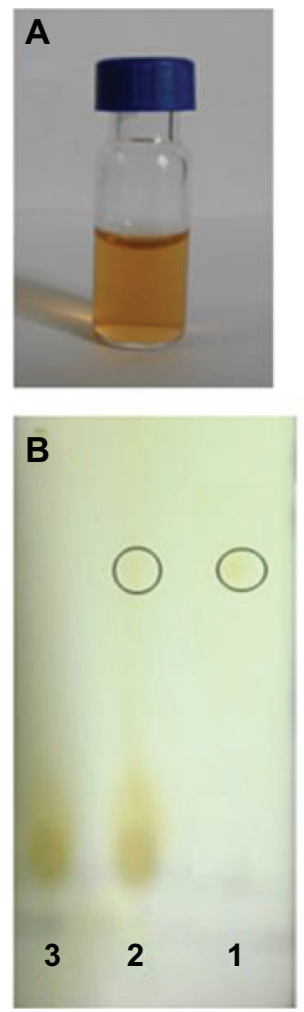

C

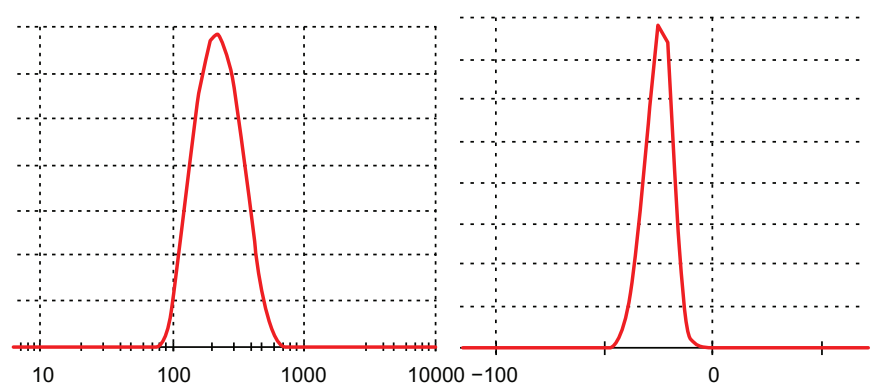

D
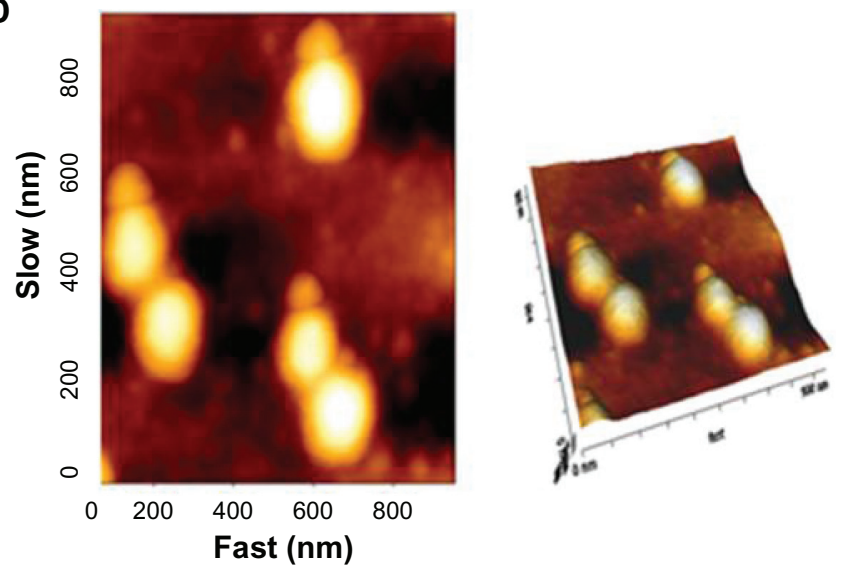

Figure 4 Characterization of DMA-C60-NGR. (A) Photos of DMA-C60-NGR in PBS buffer; (B) thin layer silica gel chromatography image of I-(NGR), 2-(NGR mechanical mixing with the DMA-C60), and 3-(DMA-C60-NGR); (C) size and zeta potential of DMA-C60-NGR; (D) AFM images of DMA-C60-NGR.

Abbreviations: DMA-C60, diadduct malonate derivative of C60; NGR, (Asn-Gly-Arg) peptide.

preparation. Thin layer silica gel chromatography results (Figure 4B) showed that there was no free NGR spot after reaction with NGR peptides, while there were visible NGR spots when they were mechanically mixed with DMA-C60, which demonstrated that NGR had completely attached to the surface of DMA-C60.

\section{Preparation and characterization of DMA-C60-NGR-2ME}

We conjugated $2 \mathrm{ME}$ to DMA-C60-NGR through physisorption. We developed a fullerene-2ME (DMA-C602ME-NGR), and 2ME was adsorbed on $\mathrm{C} 60$ through a simple physical adsorption. 2ME loading on C60-C60-NGR was confirmed by a strong absorption peak at around $288 \mathrm{~nm}$ over the DMA-C60-NGR background (Figure 5B). DMAC60-NGR-2ME was stable in water (Figure 5A), cell culture medium, and plasma of mice over multiple weeks without significant aggregation at a ratio of DMA-C60-NGR to 2ME of about 1:1.4 (weight-weight). The amount of $2 \mathrm{ME}$ loaded on DMA-C60-NGR was calculated to be $140.1 \mathrm{wt} \%$, a value far beyond carbon nanotubes, ${ }^{37,38}$ which were always below $100 \mathrm{wt} \%$. Our results indicated that DMA-C60-NGR is a promising material for drug delivery. Dynamic light scattering showed that size and zeta potential of DMAC60-2ME-NGR were $169.7 \pm 2.9 \mathrm{~nm}$ and $-26.7 \pm 1.9 \mathrm{mV}$, respectively (Figure 6A and B), and the results of the AFM images were consistent with the above results (Figure 6C). The size and zeta potential of DMA-C60-2ME-NGR were consistent with DMA-C60-NGR, indicating that $2 \mathrm{ME}$ conjugation did not change the size and zeta potential of the drug delivery system. From a pharmacokinetic standpoint, nanoparticles less than $5 \mathrm{~nm}$ are reportedly cleared by the kidney, ${ }^{39}$ while larger nanoparticles have been reported to preferentially home into tumors through leaky tumor neovasculature as a result of the enhanced permeability and retention effect. ${ }^{39}$ The size of DMA-C60-2ME-NGR opens up the possibility of targeting tumors withou $t$ being cleared rapidly by kidney.

\section{DMA-C60-NGR of photosensitization of MCF-7 cells}

Cytotoxic effects in the absence of light were studied using different concentrations of DMA-C60-NGR $(0.5-10 \mu \mathrm{g} / \mathrm{mL})$ for 24 hours of incubation. DMA-C60-NGR did not show 


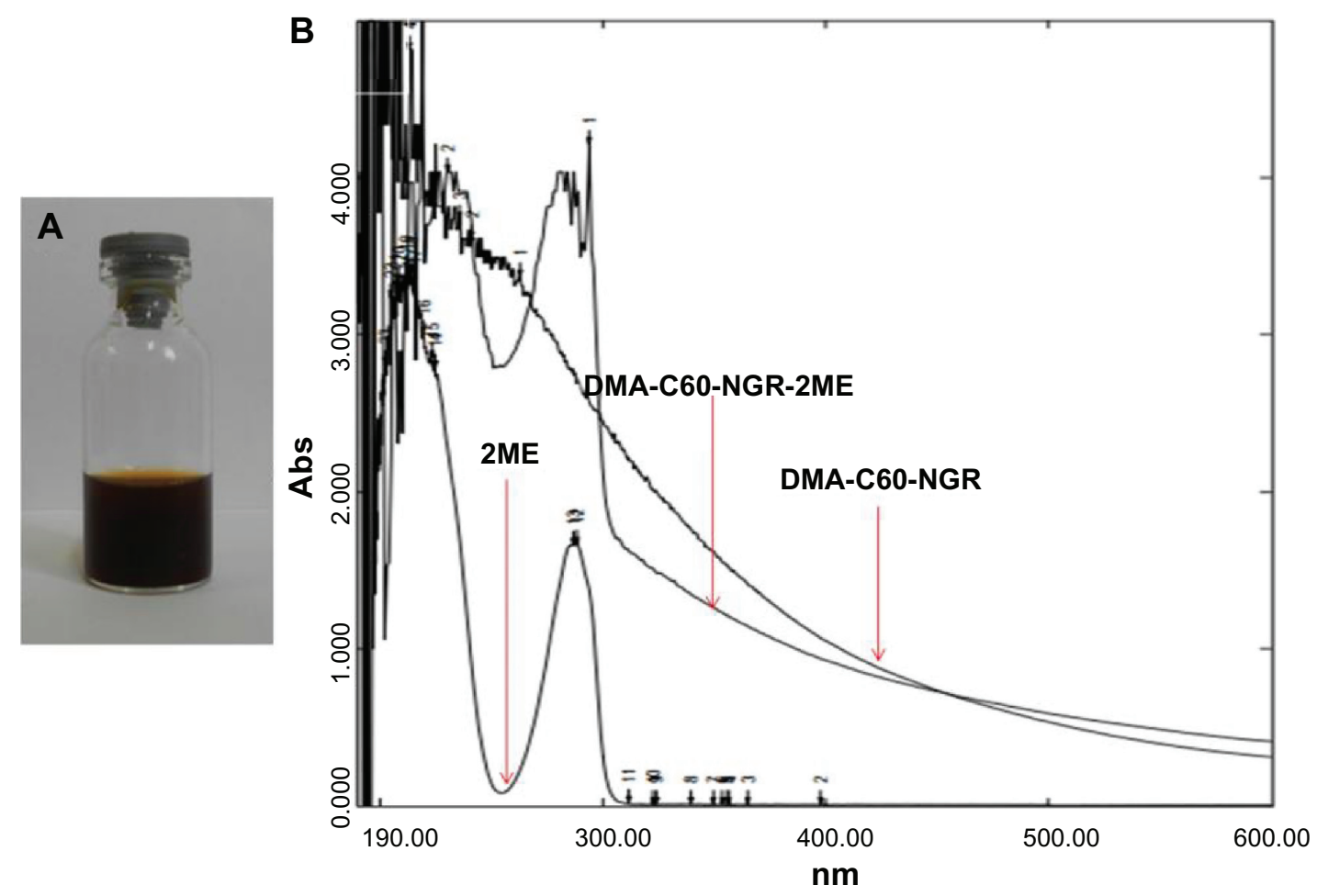

Figure 5 Characterization of DMA-C60-NGR-2ME. (A) Photos of DMA-C60-NGR-2ME in water; (B) UV spectrum of DMA-C60-NGR-2ME, DMA-C60-NGR and 2ME. Abbreviations: DMA-C60, diadduct malonate derivative of C60; NGR, Asn-Gly-Arg peptide; 2ME, 2-methoxyestradiol.

A

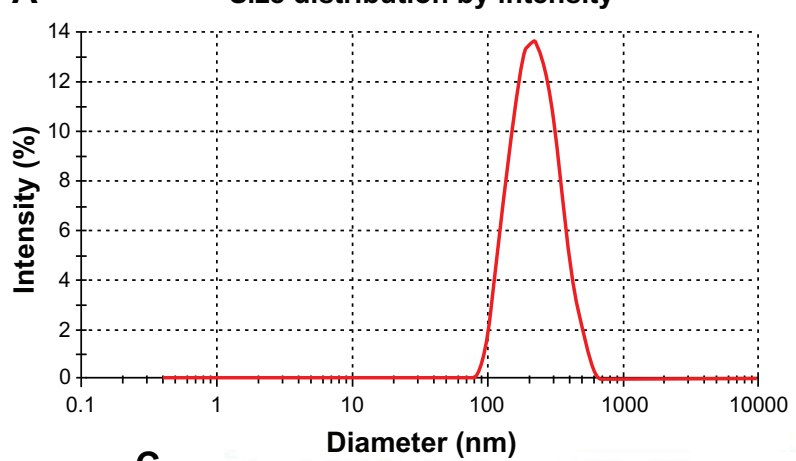

C

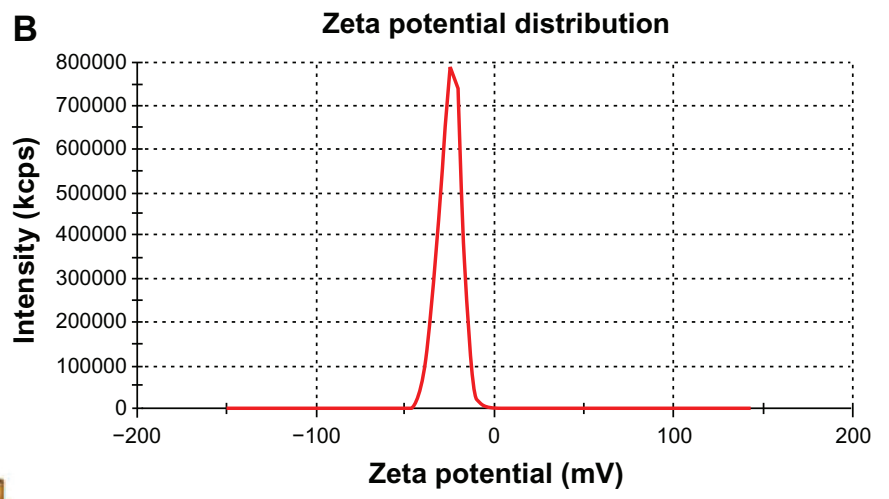

B
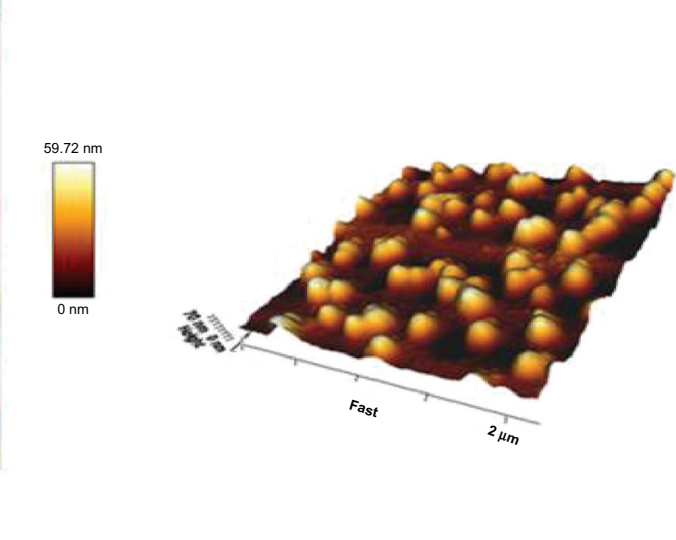

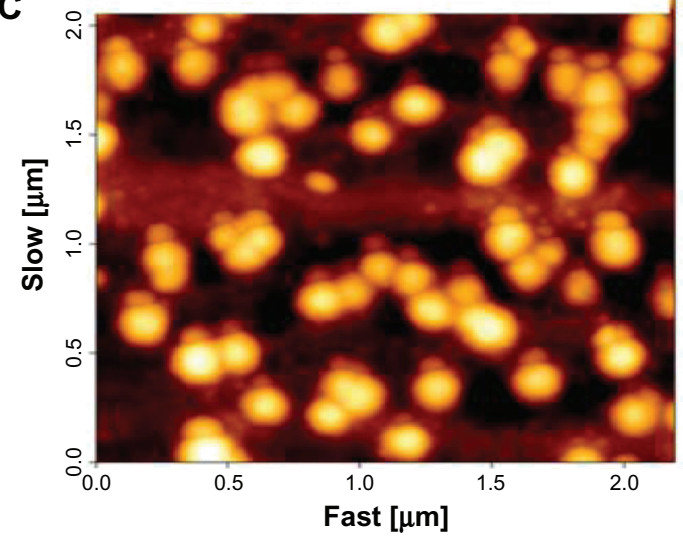

Figure 6 Characterization of DMA-C60-2ME-NGR. (A) Size of DMA-C60-2ME-NGR; (B) zeta potential of DMA-C60-2ME-NGR; and (C) AFM images of DMA-C602ME-NGR.

Abbreviations: DMA-C60, diadduct malonate derivative of C60; NGR, Asn-Gly-Arg peptide; 2ME, 2-methoxyestradiol. 


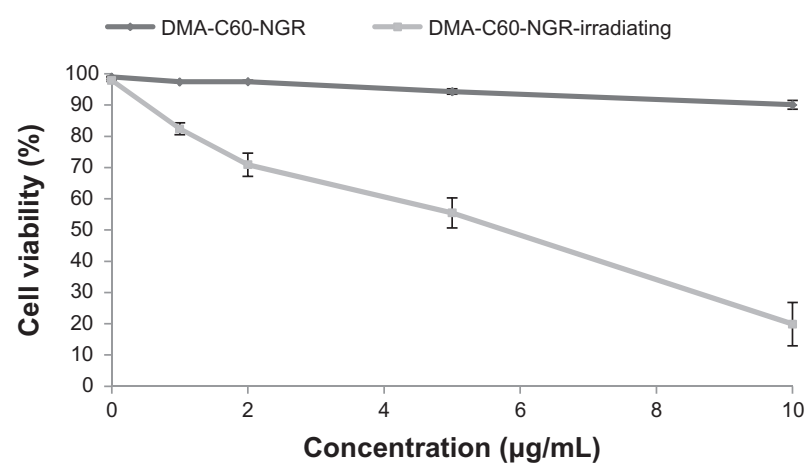

Figure 7 Viability of MCF-7 cells exposed to visible light for I hour after incubation for 24 hours.

Note: Data are presented as mean \pm standard deviation $(n=3)$.

Abbreviations: DMA-C60, diadduct malonate derivative of C60; NGR, Asn-GlyArg peptide.

toxicity at the evaluated concentrations in the absence of light (Figure 7).

After incubation with different concentrations of DMAC60-NGR for 24 hours followed by visible light irradiation for 1 hour, the viability of cells was tested by SRB assay. This test revealed that a decrease in cell viability was dependent on DMA-C60-NGR concentrations. Higher photodynamic inactivation of cell viability $(\sim 19.88 \%$, Figure 7$)$ was found in MCF-7 cells treated with $10 \mu \mathrm{g} / \mathrm{mL}$ of DMA-C60-NGR and visible light irradiation for 1 hour. Death of MCF-7 cells cultured without DMA-C60-NGR was not observed after visible light irradiation for 1 hour (Figure 7). A significant difference $(P<0.05)$ between the groups of DMA-C60NGR with and without irradiation was found. We conclude that MCF-7 cell death was caused by photosensitization of DMA-C60-NGR.

\section{Generation of intracellular ROS}

The reactive intracellular probe $\mathrm{CM}-\mathrm{H}_{2}$ DCFDA was used to determine ROS (particularly hydrogen peroxide) produced
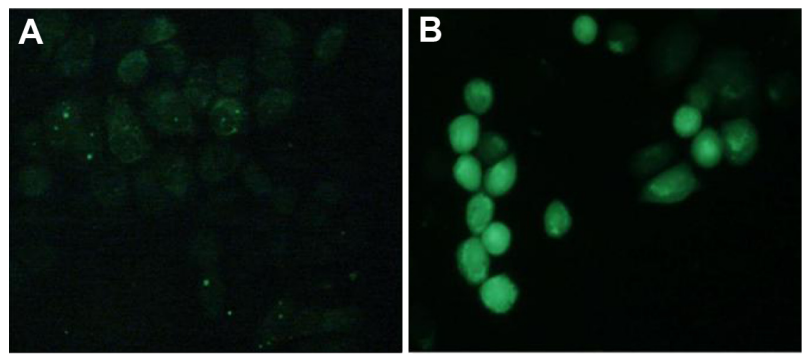

Figure 8 Fluorescence microscopic images of MCF-7 cells incubated with intracellular ROS probe $\mathrm{H}_{2} \mathrm{DCFDA}$ and illuminated with $532 \mathrm{~nm}$ laser for 5 minutes. (A) H2DCFDA without DMA-C60-NGR; (B) DMA-C60-NGR $(5 \mu \mathrm{g} / \mathrm{mL})+\mathrm{H}_{2}$ DCFDA.

Abbreviations: DMA-C60v diadduct malonate derivative of C60; NGR, Asn-Gly-Arg peptide H2DCFDA; 5-(and-6)-chloromethyl-2' -7' -dichlorodihydrofluoresceindiacetate. by cells treated with DMA-C60-NGR and irradiation. Figure 8 shows the fluorescence micrographs of illuminated MCF-7 cells incubated with the $\mathrm{H}_{2}$ DCFDA probe in medium with or without DMA-C60-NGR $(5 \mu \mathrm{g} / \mathrm{mL})$ for 24 hours. We observed trace green fluorescence in cells treated with probe $\mathrm{H}_{2}$ DCFDA alone but strong fluorescence evenly distributed throughout cells treated with probe $\mathrm{H}_{2}$ DCFDA and DMA-C60-NGR, indicating that generation of intracellular ROS was induced by DMA-C60-NGR under irradiation. This result is consistent with other C60 derivatives. ${ }^{34,40}$ DPM and NGR surface modification of $\mathrm{C} 60$ does not change the nature of the C60 nucleus. Therefore, DMA-C60-NGR is cytotoxic with irradiation and can be used as a cancer therapeutic photosensitizer.

\section{DNA fragmentation caused by DMA-C60-NGR under irradiation}

No DNA fragmentation was present in total cells from the control group or those subjected to treatment either with DMA-C60-NGR or light alone, as reveled by electrophoretic analysis (Figure 9). These results indicate that MCF-7 cells treated with DMA-C60-NGR $(5 \mu \mathrm{g} / \mathrm{mL})$ under visible light led to the DNA fragmentation. We analyzed the images with comet assay software project (CASP) software, which showed that the content of tail DNA represents the degree of DNA damage in MCF-7 cells. Compared with the control group, DMA-C60-NGR with illumination had a significant difference $(P<0.05)$ in the content of tail DNA. These DNA fragmentations confirmed MCF-7 cell apoptosis after treatment of DMA-C60-NGR with light, suggesting that DMA-C60-NGR could be further explored as a therapeutic cancer photosensitizer.
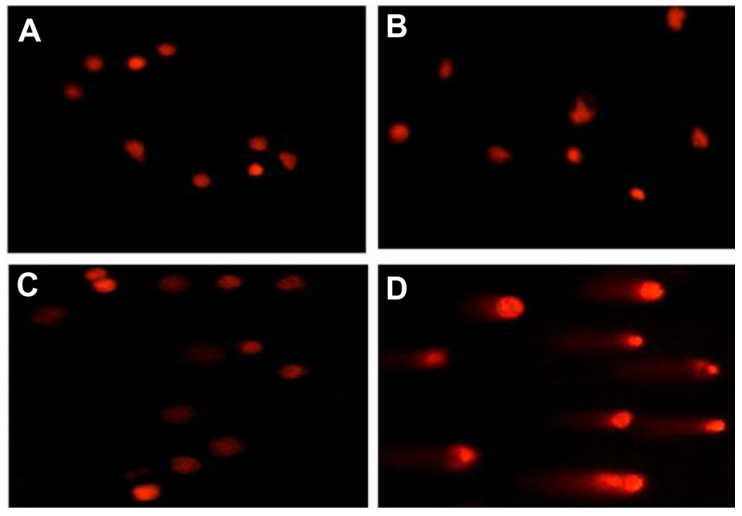

Figure 9 Images of single cell gel electrophoresis for DNA damage. (A) Untreated cells; (B) cells exposed to visible light alone for I hour; (C) cells treated with $5 \mu \mathrm{g} / \mathrm{mL}$ of DMA-C60-NGR alone for 24 hours; and (D) cells treated with $5 \mu \mathrm{g} / \mathrm{mL}$ of DMA-C60-NGR for 24 hours and then exposed to visible light for I hour.

Abbreviations: DMA-C60, diadduct malonate derivative of C60; NGR, Asn-GlyArg peptide. 

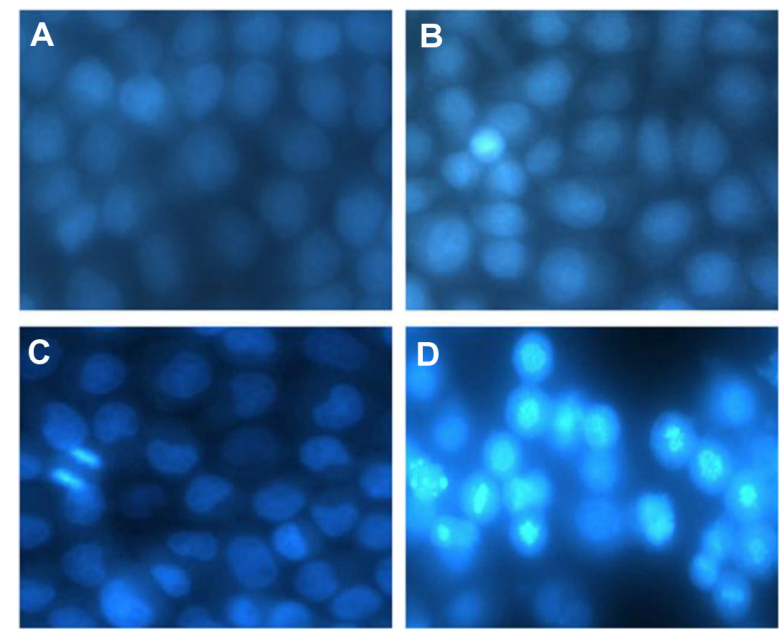

Figure 10 Fluorescence photomicrographs of MCF-7 cells stained with Hoechst-33258. (A) Untreated cells; (B) cells exposed to visible light alone for I hour; (C) cells treated with $5 \mu \mathrm{g} / \mathrm{mL}$ of DMA-C60-NGR alone for 24 hours; and (D) cells treated with $5 \mu \mathrm{g} / \mathrm{mL}$ of DMA-C60-NGR for 24 hours and then exposed to visible light for I hour.

Abbreviations: DMA-C60, diadduct malonate derivative of C60; NGR, Asn-GlyArg peptide.

\section{DMA-C60-NGR leading to apoptosis of MCF-7 cells}

After staining with Hoechst-33258, morphological changes were found in MCF-7 cells incubated with $5 \mu \mathrm{g} / \mathrm{mL}$ DMA-C60-NGR for 24 hours. Numerous apoptotic cells $(69 \%)$ appeared after incubation for 24 hours and irradiation for 1 hour. Nuclear morphology (Figure 10) indicated that cells treated with either exposure to visible light alone for 1 hour (Figure 10B) or $5 \mu \mathrm{g} / \mathrm{mL}$ of DMAC60-NGR alone for 24 hours (Figure 10C) were in a normal state without apoptosis; however, most cells treated with DMA-C60-NGR and light were in an apoptotic state. An apoptotic cell was identified by cell rounding, shrinkage, and deformation and by formation of apoptotic bodies ${ }^{41,42}$ (Figure 10D). We demonstrated that both DMA-C60NGR and irradiation play an important role in apoptosis of MCF-7 cells.

\section{NGR enhances cell uptake of DMA-C60-NGR}

To track DMA-C60-NGR inside cells, DMA-C60-NGR was labeled with FITC through $\pi-\pi$ stacking of C60 with FITC. Fluorescence microscopy was applied to track the location of fluorescent-labeled C60 inside cells (Figure 11). Little FITC was observed inside MCF-7 cells treated with FITC alone, indicating that FITC itself cannot permeate MCF-7 cells. However, large FITC was observed inside MCF-7 cells treated with DMA-C60-FITC or DMA-C60NGR-FITC, suggesting that DMA-C60-FITC or DMA-C60NGR-FITC can be effectively delivered into MCF-7 cells. As Figure 11 shows, the uptake of DMA-C60-NGR-FITC and

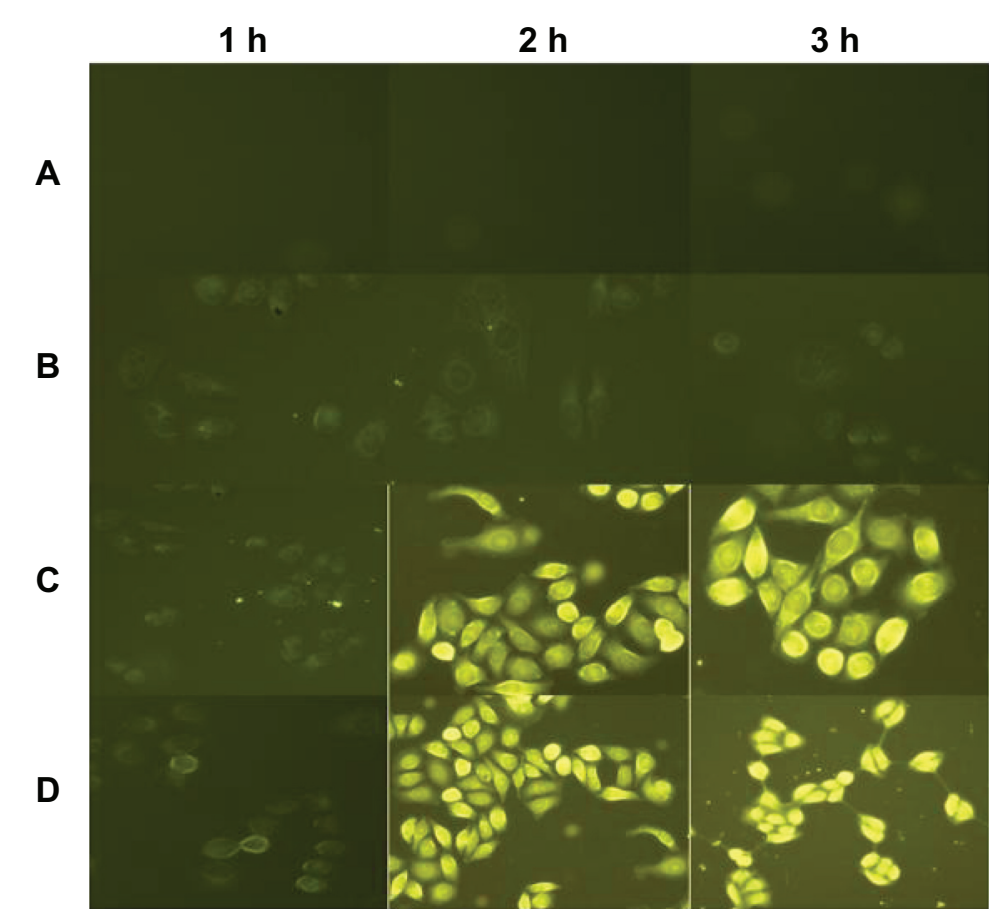

Figure II Fluorescence microscopic images of MCF-7 cells. (A) Control group; (B) FITC alone; (C) DMA-C60-FITC; and (D) DMA-C60-NGR-FITC at I, 2, and 3 hours.

Abbreviations: DMA-C60, diadduct malonate derivative of C60; NGR, Asn-Gly-Arg peptide; FITC, fluorescein isothiocyanate. 
DMA-C60-FITC by MCF-7 cells is time dependent from 1 hour to 3 hours. Interestingly, the uptake of DMA-C60NGR-FITC by MCF-7 cells was faster than that of DMAC60-FITC, and more DMA-C60-NGR-FITC was found in cytoplasm of MCF-7 cells at 3 hours than DMA-C60-FITC, suggesting that NGR enhanced cell uptake of DMA-C60 and located DMA-C60 in the cytoplasm under the applied conditions.

\section{Promoted growth inhibition of MCF-7 cells by 2 ME in DMA-C60- 2ME-NGR}

We found no significant inhibition effect of DMA-C60-NGR and DMA-C60 on MCF-7 cells up to the concentration of $20 \mu \mathrm{g} / \mathrm{mL}$ (Figure 12), suggesting that DMA-C60-NGR and DMA-C60 under the applied conditions without irradiation were not cytotoxic to MCF-7 cells.

Growth of MCF-7 cells was inhibited by $2 \mathrm{ME}$ in the DMA-C60-2ME-NGR and DMA-C60-2ME groups at 24, 48 , and 72 hours compared with the $2 \mathrm{ME}$ group $(P<0.05)$ (Figure 13). A significantly higher inhibition effect on MCF-7 cells in the DMA-C60-2ME-NGR group was found compared with the DMA-C60-2ME group $(P<0.05)$ at 24 and 48 hours (Figure 13, upper and middle panels); however, no significant difference between the DMAC60-2ME-NGR and DMA-C60-2ME groups was found at 72 hours (Figure 13, lower panel). A probable explanation is that NGR promoted a faster $2 \mathrm{ME}$ transfer into cells and exerted a stronger inhibition on MCF-7 cells during the early stages; however, when the time periods were prolonged to 72 hours, the tumor-targeting advantage of NGR weakened.

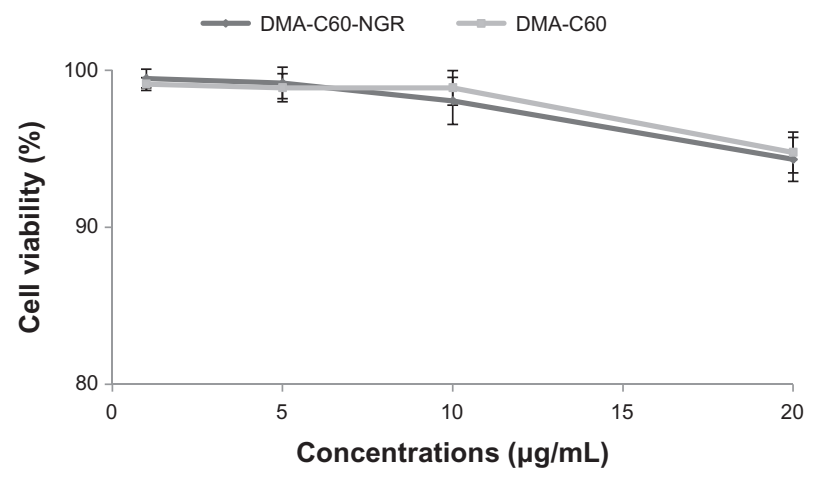

Figure 12 Cytotoxicity of DMA-C60-NGR and DMA-C60 on MCF-7 cells for 72 hours.

Note: Data are presented as mean \pm standard deviation $(n=3)$.

Abbreviations: DMA-C60, diadduct malonate derivative of C60; NGR, Asn-GlyArg peptide.
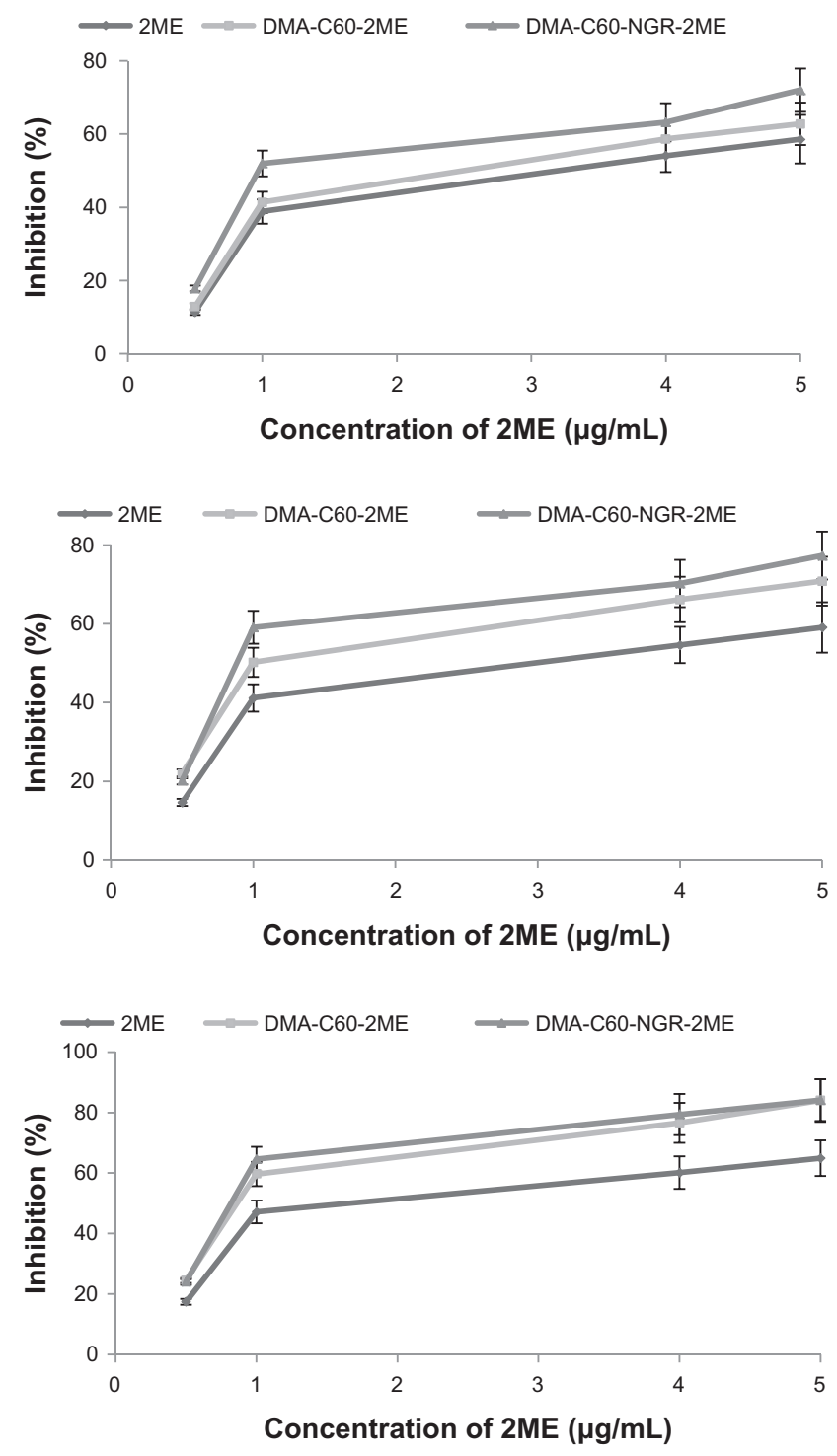

Figure 13 Inhibition efficacy of 2ME, DMA-C60-2ME, and DMA-C60-2ME-NGR on MCF-7 cells.

Notes: Upper panel, 24 hours; middle panel, 48 hours; lower panel, 72 hours. Data are presented as mean \pm standard deviation $(n=3)$.

Abbreviations: DMA-C60, diadduct malonate derivative of C60; NGR, Asn-GlyArg peptide; 2ME: 2-methoxyestradiol.

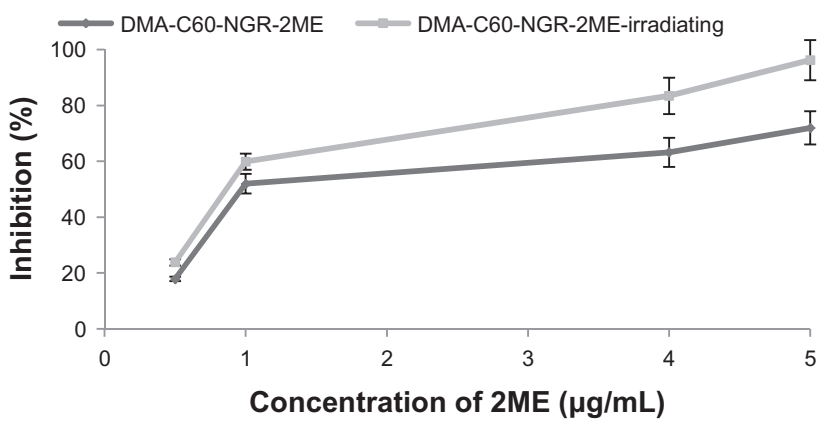

Figure 14 Inhibition efficacy of DMA-C60-2ME-NGR and DMA-C60-2ME-NGRirradiated group on MCF-7 cells for 24 hours.

Note: Data are presented as mean \pm standard deviation $(n=3)$.

Abbreviations: DMA-C60, diadduct malonate derivative of C60; NGR, Asn-GlyArg peptide; 2ME: 2-methoxyestradiol. 


\section{Synergistic enhancement of cancer therapy of PDT in combination with $2 \mathrm{ME}$ on MCF-7 cells}

Significantly higher inhibition effects were found between the DMA-C60-2ME-NGR groups with and without irradiation (Figure 14), illustrating that the photosensitization effect of DMA-C60-NGR and 2ME synergistically enhanced inhibition of MCF-7 cells. This may be because the mechanisms of action of $2 \mathrm{ME}$ relate to production of ROS, ${ }^{32}$ and this is the mechanism by which DMA-C60 kills tumor cells.

\section{Conclusion}

We evaluated DMA-C60-NGR, with the high ability to form a photo-induced charge-separated state, as a novel sensitizer with potential application in PDT. This study also presented a new tumor-targeting drug delivery system DMA-C60-2ME-NGR and the synergistic enhancement of cancer therapy using PDT induced by DMA-C60-NGR and $2 \mathrm{ME}$. We suggest that DMA-C60-NGR is promising for future cancer therapy not only as a highly efficient photosensitizer in PDT but also as a novel tumor-targeting drug delivery system.

\section{Acknowledgments}

This work was supported by grants from the National Natural Science Foundation of China (Nos 3097/3660).

\section{Disclosure}

The authors report no conflicts of interest in this work.

\section{References}

1. Isakovic A, Markovic Z, Todorovic-Markovic B, et al. Distinct cytotoxic mechanisms of pristine versus hydroxylated fullerene. Toxicol Sci. 2006;91:173-183.

2. Pinteala $M$, Dascalu A, Ungurenasu C. Binding fullerenol $\mathrm{C}(60)(\mathrm{OH})$ (24) to dsDNA. Int J Nanomedicine. 2009;4:193-199.

3. Sitharaman B, Zakharian TY, Saraf A, et al. Water-soluble fullerene (C60) derivatives as nonviral gene-delivery vectors. Mol Pharm. 2008;5:567-578.

4. Yudoh K, Karasawa R, Masuko K, Kato T. Water-soluble fullerene (C60) inhibits the osteoclast differentiation and bone destruction in arthritis. Int J Nanomedicine. 2009;4:233-239.

5. Yamago S, Tokuyama H, Nakamura E, et al. In vivo biological behavior of a water-miscible fullerene: $14 \mathrm{C}$ labeling, absorption, distribution, excretion and acute toxicity. Chem Biol. 1995;2:385-389.

6. Kang B, Yu D, Dai Y, Chang S, Chen D, Ding Y. Cancer-cell targeting and photoacoustic therapy using carbon nanotubes as "bomb" agents. Small. 2009;5:1292-1301.

7. Yih TC, Al-Fandi M. Engineered nanoparticles as precise drug delivery systems. J Cell Biochem. 2006;97:1184-1190.

8. Subramani K, Hosseinkhani H, Khraisat A, Hosseinkhani M, Pathak Y. Targeting nanoparticles as drug delivery systems for cancer treatment. Current Nanoscience. 2009;5:135-140.
9. Partha R, Mitchell LR, Lyon JL, Joshi PP, Conyers JL. Buckysomes: fullerene-based nanocarriers for hydrophobic molecule delivery. ACS Nano. 2008;2:1950-1958.

10. Henderson BW, Gollnick SO, Snyder JW, et al. Choice of oxygenconserving treatment regimen determines the inflammatory response and outcome of photodynamic therapy of tumors. Cancer Res. 2004;64:2120-2126.

11. Triesscheijn M, Baas P, Schellens JH, Stewart FA. Photodynamic therapy in oncology. Oncologist. 2006;11:1034-1044.

12. Akiyama M, Ikeda A, Shintani T, Y. et al. Solubilisation of [60]fullerenes using block copolymers and evaluation of their photodynamic activities. Org Biomol Chem. 2008;6:1015-1019.

13. Isakovic A, Markovic Z, Nikolic N, et al. Inactivation of nanocrystalline C60 cytotoxicity by gamma-irradiation. Biomaterials. 2006;27: 5049-5058.

14. Yang X, Chen L, Qiao X, Fan C. Photo-induced damages of cytoplasmic and mitochondrial membranes by a [C60]fullerene malonic acid derivative. Int J Toxicol. 2007;26:197-201.

15. Reid PE, Brown NJ, Holen I. Breast cancer cells stimulate osteoprotegerin $(\mathrm{OPG})$ production by endothelial cells through direct cell contact. Mol Cancer. 2009;8:49.

16. Baar J, Silverman P, Lyons J, et al. A vasculature-targeting regimen of preoperative docetaxel with or without bevacizumab for locally advanced breast cancer: impact on angiogenic biomarkers. Clin Cancer Res. 2009;15:3583-3590.

17. Pasqualini R, Koivunen E, Kain R, et al. Aminopeptidase N is a receptor for tumor-homing peptides and a target for inhibiting angiogenesis. Cancer Res. 2000;60:722-727.

18. Oostendorp M, Douma K, Hackeng TM, van Zandvoort MA, Post MJ, Backes WH. Pharmacokinetics of contrast agents targeted to the tumor vasculature in molecular magnetic resonance imaging. Contrast Media and Molecular Imaging. 2010;5:9-17.

19. Luan $\mathrm{Y}, \mathrm{Xu} \mathrm{W}$. The structure and main functions of aminopeptidase $\mathrm{N}$. Curr Med Chem. 2007;14:639-647.

20. Zhang Z, Wang B, Li H, Zhou T, Zhang L. The inhibitory effects of nanosize delivery system for antisense oligonucleotide of hTERT on EC9706 cells. Cancer Biol Ther. 2007;6:329-334.

21. Colombo G, Curnis F, De Mori GM, et al. Structure-activity relationships of linear and cyclic peptides containing the NGR tumor-homing motif. J Biol Chem. 2002;277:47891-47897.

22. Pastorino F, Brignole C, Marimpietri D, et al. Vascular damage and anti-angiogenic effects of tumor vessel-targeted liposomal chemotherapy. Cancer Res. 2003;63:7400-7409.

23. Garde SV, Forte AJ, Ge M, et al. Binding and internalization of NGR-peptide-targeted liposomal doxorubicin (TVT-DOX) in CD13-expressing cells and its antitumor effects. Anti-Cancer Drug. 2007;18:1189-1200.

24. Sutherland TE, Anderson RL, Hughes RA, et al. 2-Methoxyestradiol - a unique blend of activities generating a new class of anti-tumour/anti-inflammatory agents. Drug Discov Today. 2007;12:577-584.

25. Newman SP, Leese MP, Purohit A, et al. Inhibition of in vitro angiogenesis by 2-methoxy- and 2-ethyl-estrogen sulfamates. Int $J$ Cancer. 2004;109:533-540.

26. Funakoshi T, Birsner AE, D'Amato RJ. Antiangiogenic effect of oral 2-methoxyestradiol on choroidal neovascularization in mice. Exp Eye Res. 2006;83:1102-1107.

27. Ireson CR, Chander SK, Purohit A, et al. Pharmacokinetics and efficacy of 2-methoxyoestradiol and 2-methoxyoestradiol-bis-sulphamate in vivo in rodents. Br J Cancer. 2004;90:932-937.

28. Nair SK, Verma A, Thomas TJ, et al. Synergistic apoptosis of MCF-7 breast cancer cells by 2-methoxyestradiol and bis(ethyl)norspermine. Cancer Lett. 2007;250:311-322.

29. Van Zijl C, Lottering ML, Steffens F, Joubert A. In vitro effects of 2-methoxyestradiol on MCF-12A and MCF-7 cell growth, morphology and mitotic spindle formation. Cell Biochem Funct. 2008;26: $632-642$. 
30. Gong QF, Liu EH, Xin R, Huang XN, Gao N. 2ME and 2OHE2 exhibit growth inhibitory effects and cell cycle arrest at G2/M in RL95-2 human endometrial cancer cells through activation of p53 and Chk1. Mol Cell Biochem. 2011;352:221-230.

31. Pribluda VS, Gubish ER Jr, Lavallee TM, Treston A, Swartz GM, Green SJ. 2-Methoxyestradiol: an endogenous antiangiogenic and antiproliferative drug candidate. Cancer Metastasis Rev. 2000;19: 173-179.

32. Ireson CR, Chander SK, Purohit A, et al. Pharmacokinetics and efficacy of 2-methoxyoestradiol and 2-methoxyoestradiol-bis-sulphamate in vivo in rodents. Brit J Cancer. 2004;90:932-937.

33. Cheng F, Yang X, Zhu H, Sun J, Liu Y. Synthesis of oligoadducts of malonic acid C60 and their scavenging effects on hydroxyl radical. J Phys Chem Solids. 2000;61:1145-1148.

34. Wang L, Zhang M, Zhang N, et al. Synergistic enhancement of cancer therapy using a combination of docetaxel and photothermal ablation induced by single-walled carbon nanotubes. Int J Nanomedicine. 2011;6:2641-2652.

35. Ray A, Santhosh K, Chattopadhyay S, Samanta A, Bhattacharya S. Spectroscopic and theoretical investigations on effective and selective interaction of fullerenes C60 and C70 with a derivatized Zn-phthalocyanine: stabilization of charge-recombined state by side-on approach of C70. J Phys Chem A. 2010;114:5544-5550.

36. Wang L, Zhang M, Zhang N, et al. Synergistic enhancement of cancer therapy using a combination of docetaxel and photothermal ablation induced by single-walled carbon nanotubes. Int J Nanomedicine. 2011;6:2641-2652.
37. Liu Z, Sun X, Nakayama-Ratchford N, Dai H. Supramolecular chemistry on water-soluble carbon nanotubes for drug loading and delivery. ACS Nano. 2007;1:50-56.

38. Murakami T, Ajima K, Miyawaki J, Yudasaka M, Iijima S, Shiba K. Drug-loaded carbon nanohorns: adsorption and release of dexamethasone in vitro. Mol Pharm. 2004;1:399-405.

39. Peer D, Karp JM, Hong S, Farokhzad OC, Margalit R, Langer R. Nanocarriers as an emerging platform for cancer therapy. Nat Nanotechnol. 2007;2:751-760.

40. Hu Z, Zhang C, Huang Y, Sun S, Guan W, Yao Y. Photodynamic anticancer activities of water-soluble $\mathrm{C}(60)$ derivatives and their biological consequences in a HeLa cell line. Chem Biol Interact. 2012;195:86-94.

41. Noori S, Hassan ZM. Tehranolide inhibits proliferation of MCF-7 human breast cancer cells by inducing G0/G1 arrest and apoptosis. Free Radic Biol Med. 2012;52:1987-1999.

42. Chong HZ, Rahmat A, Yeap SK, et al. In vitro cytotoxicity of Strobilanthes crispus ethanol extract on hormone dependent human breast adenocarcinoma MCF-7 cell. BMC Complement Altern Med. 2012;12:1-10.
International Journal of Nanomedicine

\section{Publish your work in this journal}

The International Journal of Nanomedicine is an international, peerreviewed journal focusing on the application of nanotechnology in diagnostics, therapeutics, and drug delivery systems throughout the biomedical field. This journal is indexed on PubMed Central, MedLine, CAS, SciSearch $\AA$, Current Contents ${ }^{\circledR} /$ Clinical Medicine,

\section{Dovepress}

Journal Citation Reports/Science Edition, EMBase, Scopus and the Elsevier Bibliographic databases. The manuscript management system is completely online and includes a very quick and fair peer-review system, which is all easy to use. Visit http://www.dovepress.com/ testimonials.php to read real quotes from published authors. 